\title{
THE INFLUENCE OF WORKFORCE DIVERSITY ON PERFORMANCE OF EMPLOYEE IN PRIVATE BANKING SECTOR OF PAKISTAN
}

\author{
Sobia Iqbal ${ }^{*}$ \\ Khalid Mehmood Iraqi ${ }^{* *}$ \\ Tariq Rafi ${ }^{* * *}$
}

\begin{abstract}
This is an era of globalization, and to maximize the competitive advantage, the banking industry is acknowledging and recognizing Human Resource practices and contributing their best to employ the organizational resources in best productive manner so that they can excel and enjoy competitive edge. Number of factors are affecting on performance of the employee. This research paper is mainly intended to explore the influence of employee diversity on the performance of employee in Private Banking business of Pakistan. Specifically in this paper, the performance of the employee in a banking sector has been predicted by the influence of employee diversity with respect to their education, age, gender, and ethnicity. The data was collected from 203 private banking representatives (serving on different positions at UBL, $H B L$, and $M C B$ ) by a convenience sampling method. In order to identify the relationship, the data has been tested by SPSS Regression and correlation analysis methods. Research findings suggested that the organizations with specific reference to banking sector should plan, design and execute the policies, practices and strategies that have a wide range canvas inclusive every individual employee and workforce diversities.
\end{abstract}

Keywords: Employee performance; employee diversity; ethnicity; private banking

\section{Introduction}

Globalization has varied compositions in terms of innovations, advancements, demographic, immigrations, economic and political stability and makes the general workforce more and more adaptable working in the banking industry ${ }^{1}$.

In developing Asian countries like Pakistan, unfortunately diversity has not recognized as a modest resource of success. The social life has recognized ethnicity and gender difference (male domination) as major component in working organizations. Therefore many researchers are trying to explore different approaches to serve better in the process of accepting and respecting the differences and empowering the organizations with the most effective and efficient diversified workforce.

\footnotetext{
"Sobia Iqbal, Ph.D. Scholar, Department of Public Administration, University of Karachi

${ }_{* * *}^{* *}$ Khalid Mehmood Iraqi, Ph.D. Professor, Department of Public Administration, University of Karachi

**** Tariq Rafi, Ph.D. Professor, Founding Vice Chancellor, Jinnah Sindh Medical University, Karachi

${ }^{1}$ Guest, D.E. 'Human Resource Management and Performance: A Review and a Research Agenda', International Journal of Human Resource Management (UK: Tylor \& Francis, 1997), 8: 263-76.
} 
Innovative progressions and the manifestation of global economy has taken global talent and common people around the world more than ever. As a result, not only Businesses, SMEs and even large organization but educational institutions are facing global competition. This change is automatically giving challenges to almost everyone to observe and implement their strategies. This assimilates that one major step can have the power to change the whole structure of standard processes and develop the best possible and competitive skilled manpower.

Groups or Institutions that take pro-active measures and develop stratagems and SOPs to deliver the idea will surely enjoy the opportunity and competitive advantage with higher rate of acceptance. To keep up the market leading position and success, one shall utilize all of its abilities to determine the indispensable strengths that will support the organization to better lead and cope with all associates/affiliates, for example, competitive skilled manpower in developed working environment. In an increasing tendency of diversification in today's skilled employees, an organization should develop a better vantage point and practice innovative tactics and policies to be more lucrative.

Employee retention is another important area to be catered as trained workforce and contented employees are an asset to any organization. Employee resources are very crucial and reflect high dependency to any business success or failure. Above examinations is a view point of the influence in employees' diversification and performances in Pakistani banking sector.

Diversification can be recognized with large and small sized institutions that are now revolving to be much more heterogeneous with various cultures, ethnicity, age, gender, educational background, race, and religion ${ }^{2}$. Diversification at a work place has dynamic consequences and effects toward organizational procedures and operational practices. This may also vary depending upon different type of manpower such as culture, gender, race, age, and ethnicity, educational and religious contexts ${ }^{3}$.

Unfortunately, diversity is understood superficial and in a rigid and narrow perspective, predominantly highlighting the disputes of gender or race. It facilitates the working directive for safe passage to certain influential team members or groups. We use broader meaning and reasoning of diversification covering a maximum share of all qualities that an individual may have. This practice also inspires and encourages them, thus reflects on their emotional needs, perceptions and performance.

\section{Problem Statement}

In this modern era, diverse organizational structure is becoming an interesting issue worldwide. In fact some of the countries made it compulsory for employees from different age, gender, backgrounds to showcase that they support diversification in their

\footnotetext{
${ }^{2}$ Felled, L.H., Eisenhardt, K.M. and Xin, K.R. 'Exploring the Black Box: An Analysis of Work Group Diversity, Conflict and Performance', Administrative Science Quarterly (NY: Sage journal, 1999), 44: 1-28. ${ }^{3}$ Fleischmann, K. R., et al "Designing Educational Cases for Intercultural Information Ethics: The Importance of Diversity, Perspectives, Values, and Pluralism." Journal of Education for Library and Information Science (Canada: University of Toronto Press, 2009): 4-14
} 
working environment. As this issue has been highlighted on a broader scale for many decades, it is becoming global issue and becoming an important factor for customers/clients to choose those organizations which are actively supporting and carefully employing diverse workforce.

If any organization campaigns to be vigorous and lucrative must have a broader vantage point and a fundamental sense of responsibility to ensure that employee diversity as a part of daily organizational routines and commercial activities ${ }^{4}$. Considering impacts of diverse personnel on any company's outcome such as, organizational profitability, employee appraisals and company revenue as well as proper diversification in management, has developed critical implications on the success of organizations ${ }^{5}$.

These tendencies were originally identified in 1980s and acknowledged as an undeveloped platform for every business ventures to come up with innovative and artistic strategies to attain untouched markets and comprehensive to reach, maintain and sustain a competitive edge over competitors ${ }^{6}$. In this Contemporary world, staff is much more diverse in its composition than it used to be in past, due to modern technology and other influential aspects, such as migration and economic elements like globalization ${ }^{7}$.

The marginal labor force in the United States is predicted to grow from more than $16 \%$ in 2000 to an estimated 25\% in the middle of 20th century. Diverse workforce has not often stressed as much in various Asian and Gulf countries due to political influence and male dominating societies. Some cultures do not even see this as a competitive advantage instead they are reluctant to allow diversification due to a fear of losing control. For example few of those countries are Japan, Saudi Arabia and Korea. These countries were renowned as consistent with admiration to cultural context as well as very much masculine oriented structure in all characteristic of social life ${ }^{8}$. With distinguished financial and social growth in last few times, and the financial constraints and depression in 1990s, the workforce of Korea, Japan, and Saudi Arabia has undertaken major steps for necessary changes. Much new businesses, either willingly or unwillingly, accepted the strategies to downsize and cost cutting to persist ${ }^{9}$.

\section{Research Objectives}

The key drive of this research paper is to discover dissimilar categories of manpower diversity and their impact on performance of employees and their behavior in any business. It differentiates the variables as they can influence behavior of workforce

\footnotetext{
${ }^{4}$ Childs, J., et al. "Workforce Diversity: A Global HR Topic that has arrived." The future of Human Resource Management (eScholarship: California, 2005) 64: 110-118.

${ }^{5}$ Choi, S. and H. G. Rainey. "Managing Diversity in US Federal Agencies: Effects of Diversity and Diversity Management on Employee Perceptions of Organizational Performance." Public Administration Review (USA: Wiley Online Library, 2010) 70(1): 109-121.

${ }^{6}$ Thomas, R. Jr. 'From Affirmative Action to Affirming Diversity', Harvard Business Review (US: Harvard Business School Publishing, 1990), March/April.

${ }^{7}$ Guest, D.E. 'Human Resource Management and Performance: A Review and a Research Agenda', International Journal of Human Resource Management (UK: Tylor \& Francis, 1997), 8: 263-76.

${ }^{8}$ Cox, T.H. Cultural Diversity in Organizations: Theory, Research and Practice. (San Francisco: BerrettKoehler, 1993).

${ }^{9}$ Guest, D.E. Human Resource Management, Op.cit.
} 
particularly focusing to Pakistani private banking culture. Thus, improving employee's performances. This research would deliver a strategical guide that may help the industry in taking decisions and launching the business for potential fresh enthusiastic individuals who will be entering banking industry. Further, it will encounter the following elements:

a. To investigate the impression of gender diversity on performance of employee in Pakistani private banking sector.

b. To explore the current age diversity in Pakistani private banking industry.

c. To identify that how ethnicity differences are address in the performance of the worker in Pakistani private banking sector.

d. To explore the significance of educational background on performance of employee in Pakistan private banking sector.

\section{Research Questions}

a. What is the association of gender and performance of employee in Pakistani private banking sector?

b. How age diversity impact the performance of the employee in Pakistani private banking sector?

c. What is the association in ethnicity and performance of employee in Pakistani private banking sector?

d. What is the relationship of educational background and performance of employee in Pakistani private banking sector?

e. What is the influence of employee diversity in performance of employee in Pakistani private banking?

\section{Research Literature Review}

Diversification is occurrence of dissimilarity between people from an element of the social $\operatorname{order}^{10}$. Currently, the staff is more varied in genders, age, faith, sexuality, ethnicity as well as the wide ranging inhabitants who are distinguishing and exhibiting assorted mind-set, performances, needs, norms, cultures, values on place of work ${ }^{11}$. It is very clear if we carefully consider above points and observations that the mainstream of the scholars complemented on the meaning of diversification on a developed work place.

${ }^{10}$ Jackson, S. E., et al. "Recent Research on Team and Organizational Diversity: SWOT Analysis and Implications." Journal of Management (NY: Sage Journals, 2003), 29(6): 801-830.

${ }^{11}$ Watson, W.E., Kumar, K. and Michaelsen, L.K. 'Cultural Diversity's Impact on Interaction Process and Performance: Comparing Homogeneous and Divers Task Groups', (NY: Academy of Management Journal, 1993), 36: 590-602. 
The primary base of the diversification is to make no differences in age, gender, faith, society and educational background. Additionally, several sources of diversification are also there such as skills set, knowledge, talents, standards, beliefs and attitudes, characteristics and intellect, commination style and gesture of an individual or group.

There are many other areas of diversification such as radical and political belongings nepotism, educational background, friendships and solidarities, leading associates joining services skills comprising implementation of group capabilities and expertise ${ }^{12}$.

\section{Performance of the Employee}

The earlier studies of diversification suggest that diversity can be both detrimental and constructive for workplace routine ${ }^{13}$. For example, employee diversity is optimistically linked together with creativeness, improvement, advancement and crucial thinking capacities $^{14}$ and pessimistically associated with cohesiveness, teamwork, assistance and maintenance ${ }^{15}$. An excellent example of great and diverse work place is where an organization's HRM is working towards development of their employees and train them for versatility.

This behavior increases employee retention and automatically progress and supplement worker and business unit performances ${ }^{16}$. As any business performs better, that is definitely an impact of the workforce and their performances, so the opportunity cost of diverse staff at the employee level would definitely help essential and external motivational factors for them and would support them grow staff trust and faithfulness to the organization. Along these lines, this research distillates the awareness of employee augmentation through their particular exercise during recruitment and training to deal and compliment diversity at their workplace. Diversification in higher management structure in an organization integrates utmost operations with cultural divergence as a fragment of abilities of people/personnel, point of views and imagination to improve to a distinctive objective and enterprise that complimented the business unit to be more modest than other businesses ${ }^{17}$.

The connection between healthy diverse activities and performance of the business units grounded on latest studies. Diverse workplace environment subsidies to increase

${ }^{12}$ Graen, G. B. Dealing with Diversity, (IAP, 2003)

${ }^{13}$ Hamilton, B. H., et al. "Diversity and Productivity in Production Teams.", (2004), Available at SSRN 547963.

${ }^{14}$ Milliken, F.J. and Martins, L.L. 'Searching for Common Threads: Understanding the Multiple Effects of Diversity in Organizational Groups', Academy of Management Review (NY: Academy of Management, 1996), 21: 402-33.

${ }^{15}$ Felled, L.H., Eisenhardt, K.M. and Xin, K.R. 'Exploring the Black Box: An Analysis of Work Group Diversity, Conflict and Performance', Administrative Science Quarterly (NY: Sage journal, 1999), 44: 1-28.

${ }^{16}$ Adler, N. J. "Cultural Synergy: Managing the Impact of Cultural Diversity." The 1986 Annual: Developing Human Resources (CALIF: San Diego, 1986): 229-238.

${ }^{17}$ Milliken, F.J. and Martins, L.L. 'Searching for Common Threads: Understanding the Multiple Effects of Diversity in Organizational Groups', Academy of Management Review (NY: Academy of Management, 1996), 21: 402-33. 
courage and motivation towards innovation, wider vantage points, creative and versatile solutions to a problem as well as problem solving routine. ${ }^{18}$

\section{Gender Diversity}

Bigotry on the basis of gender or gender-based issues in an institution are unfortunately encouraged and defensible by broader view point, that partially describe affirmative features and hence an evident superiority to males gender ${ }^{19}$. In simplified terms, companies tend to hire more male labor/staff as compare to female since they believed that male will have higher rate of success, production and abilities to meet required results. There is a promising bond in individual sexual orientation conflicting abilities and intra-bunch assistance, especially where mostly diverse gender is concern.

In addition to sexual orientation varied potentials was categorically recognized with society execution at last this was an honest and enormous issue inside any local mindset. Generally, the most affected area of any organization based upon managerial level where all decisions are made. Gender based classification are common practice where it distributes power and authenticity rights to an individual.

\section{Age-Diversity}

Emergent age diversification issue has turning up as a vital element for most of the business units' even cultures and societies. The researches have clarified this association as communal characteristics and prearrangement. Individuals are approved to represent themselves into specific congregation on the evidence of quantifiable abilities and exhibit to collective exclusivity and self-made assumptions ${ }^{20}$. Organizations are not effectively hiring the abilities of deep-rooted aged expert personnel due to fabricated typecast theories and assumptions that they are highly paid plus will be more prone to health problems, unable to adapt company's modifications and technological advancements, may be unproductively or less productive, as compare to the young individual and effect as decline in productivity despite of organizational training investments ${ }^{21}$.

\section{Ethnicity}

Irrespective of the structure, the workforce arrangement is beneficially ending up being merged for gender, culture, age, religion, ethnicity, and sexual orientation, academic background has also intensified consequences as divergent potentials in educational institutions ${ }^{22}$. The progress in multicultural customs of the society reflects not only in

${ }^{18}$ D'Netto, B. and A. S. Sohal "Human Resource Practices and Workforce Diversity: An Empirical Assessment." International Journal of Manpower (UK: Emerald Publishing, 1999) 20(8): 530-547.

${ }^{19}$ Jackson, S. E., et al. "Recent Research on Team and Organizational Diversity: SWOT Analysis and Implications." Journal of Management (NY: Sage Journals, 2003), 29(6): 801-830.

${ }^{20}$ Cunningham, G. B. "Creating and Sustaining Gender Diversity in Sport Organizations." Sex Roles (Switzerland: Springer, 2008) 58(1-2): 136-145.

${ }^{21}$ Graen, G. B. Dealing with Diversity, (IAP, 2003).

${ }^{22}$ Watson, W.E., Kumar, K. and Michaelsen, L.K. 'Cultural Diversity's Impact on Interaction Process and Performance: Comparing Homogeneous and Divers Task Groups', (NY: Academy of Management Journal, 1993), 36: 590-602. 
education, family structure and background, religion practices but also in multiethnic groups in businesses. It has simultaneously and significantly impact employee satisfaction and organizational productivity.

The organizational internal environment has huge impact on diversity performance. Researches have proven ethnic traits diversification constructively for team work. Graen $^{23}$ argued that ethnic diversity is an effective predictor of critical thinking, problem solving and enhancing team and individual performance for the business unit as it directs them to utilize individual differences productively and optimally to meet the competitive edge. Whereas, Paauwe ${ }^{24}$ highlighted the negative aspect ethnic diversification as it may lead to conflicts and disagreement in case of societal combination and gossiping. Herring ${ }^{25}$ has further suggested keeping ethnic diversities in limited mechanism until and unless it ensures progression and advancement in organizational structure.

In extension to this different studies has addressed ethnic diversity as reason of poor performance $^{26}$, less consistent and unreliable with low positive influence on employee and team performance ${ }^{27}$.

\section{Educational Background}

Researches has identified that organizations normally discourage to hire and continue utilizing those candidate who are lacking in education, experiences and unable to upgrade their skills as per globalization need ${ }^{28}$.

Management mostly rejects to hire incompetent candidates in terms of training, insufficient education and working experience. It refers that educational background matters a lot when it comes to finding new opportunities. Literature review also supported that the candidates with strong background and interpersonal communication skills get more opportunities and ventures to explore their capabilities. Researchers also exposed that impressive experience, educational background and diversified educational and training certifications may also lead to flexible wage rates ${ }^{29}$. Paauwe, J. and

23 Ibid

${ }^{24}$ Paauwe, J. and Richardson, J. 'Introduction', International Journal of Human Resource Management (NY: Tylor \& Francis. 1997), 8: 257-62.

${ }^{25}$ Herring, B. L., et al. "Wide Range of Quasi Species Diversity during Primary Hepatitis C Virus Infection." Journal of virology (US: Scientific Society Publisher Alliance, 2005), 79(7): 4340-4346.

${ }^{26}$ Jackson, S. E., et al. "Recent Research on Team and Organizational Diversity: SWOT Analysis and Implications." Journal of Management (NY: Sage Journals, 2003), 29(6): 801-830.

${ }^{27}$ D'Netto, B. and A. S. Sohal "Human Resource Practices and Workforce Diversity: An Empirical Assessment." International Journal of Manpower (UK: Emerald Publishing, 1999) 20(8): 530-547.

${ }^{28}$ Watson, W.E., Kumar, K. and Michaelsen, L.K. 'Cultural Diversity's Impact on Interaction Process and Performance: Comparing Homogeneous and Divers Task Groups', (NY: Academy of Management Journal, 1993), 36: 590-602.

${ }^{29}$ Fleischmann, K. R., et al "Designing Educational Cases for Intercultural Information Ethics: The Importance of Diversity, Perspectives, Values, and Pluralism." Journal of Education for Library and Information Science (Canada: University of Toronto Press, 2009): 4-14 
Richardson argued that a candidate can turn up as more effective and productive for the organization if he has enough education and training for the proposed job ${ }^{30}$.

\section{Research Methodology}

The questionnaire has been disseminated within the participants with the aid of social media through WhatsApp, Facebook, Email addresses and LinkedIn and some printed forms has also been distributed due constraints in time and budget. The designed Questionnaire was created by studying and transforming diverse surveys, opinion polls, inquiry form of connected studies. Pilot study was conducted to check reliability of the questionnaire. To record the responses Five point Likert scale questionnaire was used. Over-all of 242 questionnaires were dispersed and 218 were collected out of which 203 was considered as properly filled response.

In order to investigate and relate the executed Human Resource practices and policies of private banking sector, the banks have been selected through convenience sampling and in the selected banks (UBL, HBL, MCB), the participants has been selected as per convenient sampling method focusing to identify the ones who are serving the banking sector in any position from entry level to higher management positions. The collected data was tested on Regression and Correlation model to extract the result as.

Or we can represent it as:

$$
\mathrm{Y}=\alpha+\beta_{1} X_{1}(\text { gender })+\beta_{2} X_{2}(\text { age })+\beta_{3} X_{3}(\text { ethnicity })+\beta_{4} X_{4}(\text { education })+\varepsilon_{i}
$$

Age, gender, Education and Ethnicity are considered as independent variables and performance of employee as dependent variable. $(\alpha)$ is referred as regression intercept, $\beta 1, \beta 2, \beta 3$ and $\beta 4$ as regression coefficients and $\mathrm{E}$ as error.

\section{Data Analysis and Discussion}

Table-1

Gender of the Participants of Private Banking Sector

\begin{tabular}{|c|l|c|c|c|}
\hline \multicolumn{2}{|c|}{ Gender } & Frequency & Percent & Cumulative Percent \\
\hline \multirow{4}{*}{ Valid } & Male & 107 & 52.7 & 52.7 \\
\cline { 2 - 5 } & Female & 96 & 47.3 & 100 \\
\cline { 2 - 5 } & Total & 203 & 100 & \\
\hline
\end{tabular}

Table 1 is representing the gender distribution of the participants. 96 females has participated and presenting $47.3 \%$ respondents and 107 male as $52.7 \%$ male respondents. This data is supporting the latest trend of Pakistani society where female

\footnotetext{
${ }^{30}$ Paauwe, J. and Richardson, J. 'Introduction', International Journal of Human Resource Management (NY: Tylor \& Francis. 1997), 8: 257-62.
} 
gender is progressing and getting independent and contributing in economic development of the country.

Table-2

Descriptive Statistics for Participants of the Private Sector Banks (N=203)

\begin{tabular}{|c|l|c|c|c|}
\hline \multicolumn{2}{|c|}{ Age } & F & \% & Cumulative \% \\
\hline \multirow{5}{*}{} & $20-25$ & 12 & 5.4 & 5.4 \\
\cline { 2 - 5 } & $26-30$ & 70 & 37.4 & 42.8 \\
\cline { 2 - 5 } Valid & $31-35$ & 63 & 26.7 & 69.5 \\
\cline { 2 - 5 } & $36-40$ & 41 & 23.1 & 92.6 \\
\cline { 2 - 5 } & 41 and above & 17 & 7.4 & 100.0 \\
\cline { 2 - 5 } & Total & 203 & 100.0 & \\
\hline
\end{tabular}

Table 2 is showing the variable of the age for 203 respondents from private banking of Pakistan. The table presents that out of 203 respondents, $37.4 \%$ respondents lies in 2630 age group, while $69.5 \%$ are cumulatively are $\geq$ the of age of 40 years.

The test is presenting high frequency of the employees is in their dynamic energetic years. This result is additionally supporting to the studies that suggest focusing to recruit relatively younger and mature workforce and showing bank's consistent recruitment policy.

Table-3

Correlation (Private Banking Sector)

\begin{tabular}{|c|c|c|c|c|c|c|}
\hline S. No & & $\begin{array}{l}\text { Educational } \\
\text { Background }\end{array}$ & Ethnicity & $\begin{array}{l}\text { Age } \\
\text { Diversity }\end{array}$ & $\begin{array}{l}\text { Gender } \\
\text { Diversity }\end{array}$ & $\begin{array}{l}\text { Employee } \\
\text { Performance }\end{array}$ \\
\hline & $\begin{array}{l}\text { Educational } \\
\text { Background }\end{array}$ & 1 & $.522 * *$ & $.464 * *$ & $.392 * *$ & $.235 * *$ \\
\hline & Ethnicity & & 1 & $.482 * *$ & $.547 * *$ & $.438 * *$ \\
\hline & $\begin{array}{l}\text { Age } \\
\text { Diversity }\end{array}$ & & & 1 & $.521 * *$ & $.397 * *$ \\
\hline & $\begin{array}{l}\text { Gender } \\
\text { Diversity }\end{array}$ & & & & 1 & $.520 * *$ \\
\hline & $\begin{array}{l}\text { Employee } \\
\text { Performance }\end{array}$ & & & & & 1 \\
\hline
\end{tabular}


The above Pearson correlation coefficients table is showing significant $(1 \%)$ and positive correlation for the selected variables.

Table-4

Model Summary

Employee Diversity in Private Banking Sector

\begin{tabular}{|c|c|c|c|c|}
\hline Model & R & R Square & Adjusted R Square & Std. Error of the Estimate \\
\hline 1 & $.955 \mathrm{a}$ & .913 & .901 & .37666 \\
\hline
\end{tabular}

To find the regression analysis for relation of the variables, the above model summary table is showing $\mathrm{R}=.955$, $\mathrm{R}$-Square (coefficient of determinant) is .913 showing $91.3 \%$ variance in performance of employee is which is very high.

Table-5

ANOVA

Employee Diversity in Private Banking Sector

\begin{tabular}{|l|l|r|r|r|r|c|}
\hline \multicolumn{2}{|c|}{ Model } & $\begin{array}{c}\text { Sum of } \\
\text { Squares }\end{array}$ & d.f & $\begin{array}{c}\text { Mean } \\
\text { Square }\end{array}$ & F & Sig. \\
\hline \multirow{3}{*}{1} & Regression & 13.093 & 4 & 3.273 & 23.072 & $.000^{\mathrm{b}}$ \\
\cline { 2 - 7 } & Residual & 27.949 & 197 & .142 & & \\
\cline { 2 - 7 } & Total & 41.041 & 201 & & & \\
\hline
\end{tabular}

a. Dependent Variable: Performance of the Employee

The above ANOVA table is showing high significance that rejects null hypothesis and concludes that this model can be used for further predictions. The table presents $\mathrm{F}=23.072$. It reflects significant combination of the all predictors to the impact of Employee Diversity on Performance of the employee in private banking sector. 
Table-5

Coefficients

Employee Diversity in Private Banking Sector

\begin{tabular}{|l|l|c|c|c|c|c|}
\hline \multirow{2}{*}{\multicolumn{2}{|c|}{ Model }} & \multicolumn{2}{c|}{$\begin{array}{c}\text { Unstandardized } \\
\text { Coefficients }\end{array}$} & $\begin{array}{c}\text { Standardized } \\
\text { Coefficients }\end{array}$ & T & \multirow{2}{*}{ Sig. } \\
\cline { 3 - 7 } & \multicolumn{1}{|c|}{ (Constant) } & 1.664 & Std. Error & Beta & & \\
\hline & Gender & .328 & .069 & & 6.978 & $\mathbf{. 0 6 0}$ \\
\hline 1 & Age & -.136 & .069 & -.145 & -1.967 & $\mathbf{. 0 0 1}$ \\
\hline 3 & Ethnicity & .074 & .061 & .87 & 1.210 & $\mathbf{. 0 2 0}$ \\
\hline 4 & Education & .193 & .069 & .217 & 2.787 & $\mathbf{. 0 0 6}$ \\
\hline
\end{tabular}

a. Dependent Variable: Workforce Diversity

In the above table, Gender, Age, Ethnicity and Education are representing Dependent Variable of Workforce The table is presenting Gender Diversity, reflecting very significant and positive results adding traditionalism to the prior literature for performance of employee in Pakistani private banking sector. The results are also supporting the studies that disciple negative association of performance of the employees and age diversity ${ }^{31}$.

\section{Significance of the Study}

Diversity may result in synergistic and shared performance, it reflects the outcomes of individual contribution of team member. When team members understands, respect and accepts the individual differences, they may lead with their experiences, ideas, adoptability, and flexibility with highly motivated conducive working environment.

The internal Communication mechanism can be the basic tool to evaluate and discuss the difference of opinion and suggest ideal solutions respecting individual perception, social desire and lead to fit in neutral social acceptable culture in the organization.

This study can help the top management in decision making in evaluating the role of employee diversity in optimizing the organizational productivity. It will identify the significance of HRM for private banking industry while facing and responding to the challenges of globalization exist due to information revolution and workforce diversity.

\section{Conclusion and Recommendation}

The upshots of this research paper delivers strategies to decision makers for addressing diversity management and proposes the management may not discover a speedy

${ }^{31}$ Milliken, F.J. and Martins, L.L. 'Searching for Common Threads: Understanding the Multiple Effects of Diversity in Organizational Groups', Academy of Management Review (NY: Academy of Management, 1996), 21: 402-33. 
shortcuts constructive association in organizational productivity and workforce diversity, it may take time.

Further we can conclude that:

- In order to deal with a differing working environment, relationship should assure that they adequately communicate with employees. Arrangements, security guidelines, techniques and other significant data should be projected to beat social and language barriers by utilizing pictures and interpreting images and materials at relevant points.

- It is advisable to discontinue the making of assumptions about employees from different backgrounds. Taking every employee gender individual as a single person and evaluate their achievements, strengths, weaknesses and disappointments on the individual's acceptability as against to chalk up actions to their understanding and experience.

- Assigning the Employees Diversity to work in a team or a groups may lead to let the employees more expressive and become more familiar with esteem and to respect each other as a single person principle can help social errors and separate monotonous assumptions.

- Setting standardized rules and principles for all the employees' workers regardless to their differences in ideology and foundation create a conducive environment in an organization. It assures that all the working activities ensure equality dealt with every employee.

- Recognize, and urge employees to notice, that their involvements, ideologies, foundations, differences, and cultures has no impact on the task they perform. They are treated and respected for being an individual in the organization. Examine the approaches that combine different point of views assist into activities to accomplish hierarchical objectives of the organizations.

To fabricate a divergent working environment, it is vital to choose and enlist manpower capacity from a different foundations and ideologies. It involves initiative from the individuals who are acquiring to conquer the biasness in meeting and surveying ability. There is a chance that organizations can get through biasness and hire the most educated individuals, those who best fit to the job, with correct instructions, certifications, experience, knowledge, skills and abilities. This may lead to a different working environment in conclusion. Organizations that grasp workforce diversity also need to assure the management to practice set the guidelines that ensure Labor Rights as per government policies.

It is elementary for an organization, considers and executes the policies, practices and strategies that have a wide scope to represent every individual of workforce diversity. Banking industry should welcome their employees to report their criticism with studies and suggestions to pick up a superior understanding representing the workforce diversity their perception. Their inputs (positive and negative) are worthy. Banking sector should be steady to change and adjust arrangements that might be interpreted as weaknesses or 
obstructed for workers. Apart from the composed strategies, it is necessary to assure that the non-official "rules" of organizations are disclosed to all individuals of the organization representing to culture and esteems to all professionals successfully.

Furthermore, it is suggested that studies should also ponder and compare minorities and physically disabled employees focusing on HR existing issues.

\section{Bibliography}

Acker, J. 'Gendering Organizational Theory'. In Mills, A.J. and Tancred, P. (eds) Gendering Organizational Analysis. Newbury Park, CA: (NY: Sage. 1992).

Adler, N. J. "Cultural Synergy: Managing the Impact of Cultural Diversity." The 1986 Annual: Developing Human Resources (San Diego: CALIF, 1986).

Algahtani, A. "Diversity in the Corporate Setting." International Journal of Business and Social Science (2013).4(14).

Childs, J., et al. "Workforce Diversity: A Global HR Topic that has arrived." The future of Human Resource Management (California: eScholarship, 2005).

Choi, S. and H. G. Rainey, "Managing Diversity in US Federal Agencies: Effects of Diversity and Diversity Management on Employee Perceptions of Organizational Performance." Public Administration Review (USA: Wiley Online Library, 2010) 70(1).

Cox, T.H. Cultural Diversity in Organizations: Theory, Research and Practice. (San Francisco: Berrett-Koehler, 1993).

Cunningham, G. B. "Creating and Sustaining Gender Diversity in Sport Organizations." Sex Roles (Switzerland: Springer, 2008) 58(1-2).

D'Netto, B. and A. S. Sohal (1999). "Human Resource Practices and Workforce Diversity: An Empirical Assessment." International Journal of Manpower (UK: Emerald Publishing, 1999) 20(8).

Felled, L.H., Eisenhardt, K.M. and Xin, K.R. (1999) 'Exploring the Black Box: An Analysis of Work Group Diversity, Conflict and Performance', Administrative Science Quarterly (NY: Sage journal, 1999).

Fleischmann, K. R., et al "Designing Educational Cases for Intercultural Information Ethics: The Importance of Diversity, Perspectives, Values, and Pluralism.” Journal of Education for Library and Information Science (Canada: University of Toronto Press, 2009).

Graen, G. B. Dealing with Diversity, (IAP, 2003) 
Guest, D.E. (1997) 'Human Resource Management and Performance: A Review and a Research Agenda', International Journal of Human Resource Management (UK: Tylor $\&$ Francis, 1997).

Hamilton, B. H., et al. (2004). "Diversity and Productivity in Production Teams" Available at SSRN 547963.

Herring, B. L., et al. "Wide Range of Quasi Species Diversity during Primary Hepatitis C Virus Infection." Journal of Virology (US: Scientific Society Publisher Alliance, 2005), 79(7).

Jackson, S. E., et al. "Recent Research on Team and Organizational Diversity: SWOT Analysis and Implications." Journal of Management (NY: Sage Journals, 2003), 29(6).

Jehn, K. A., et al. "Why Differences Makes a Difference: A Field Study of Diversity, Conflict and Performance in Workgroups." Administrative Science Quarterly, (1999), 44(4).

Kulik, C. T. and L. Roberson "Common Goals and Golden Opportunities: Evaluations of Diversity Education in Academic and Organizational Settings." Academy of Management Learning \& Education, (2008), 7(3).

Milliken, F.J. and Martins, L.L. 'Searching for Common Threads: Understanding the Multiple Effects of Diversity in Organizational Groups', Academy of Management Review (NY: Academy of Management, 1996).

Paauwe, J. and Richardson, J. 'Introduction', International Journal of Human Resource Management (NY: Tylor \& Francis. 1997).

Prasad, P., Mills, A.J., Elmes, M. and Prasad, A. "Managing the Organizational Melting Pot: Dilemmas of Workforce Diversity". Thousand Oaks, CA: (NY: Sage, 1997)

Sanchez, J.I. and Brock, P. 'Outcomes of Perceived Discrimination among Hispanic Employees: Is Diversity Management a Luxury or a Necessity?' (NY: Academy of Management Journal, 1996).

Thomas, R. Jr. 'From Affirmative Action to Affirming Diversity', Harvard Business Review (US: Harvard Business School Publishing, 1990), March/April.

Watson, W.E., Kumar, K. and Michaelsen, L.K. 'Cultural Diversity's Impact on Interaction Process and Performance: Comparing Homogeneous and Divers Task Groups', (NY: Academy of Management Journal, 1993). 